\title{
韓国大邱市の大規模都市緑地の保全と活用に関する研究
}

\section{A Study on the Conservation and Practical Use of Large Scale Urban Forest in Teagu, Korea}

權 奇燦*

Keechan KWUN

\begin{abstract}
摘要 : 本研究では，韓国の大邱市に存在する 7 カ所の大規模な都市緑地を対象として，都市緑地が保 有する物的ポテンシャルの評価結果と居住者の緑地に対する意識評価結果との相互関係を捉えること により, 保全と活用の視点から都市緑地の整備の方向性を探った。その結果, 大邱市での都市緑地の 利用は，江戸期の日本の物見遊山的利用が中心となっており，この歴史的文化的背景は今後の緑地整 備において充分配慮すべき事項であることや緑地が保有する自然環境を背景として, 緑地利用の活性 化や微気象調節効果, 自然性の供給効果などが顕在化していることから, 自然環境の保全を基調とし た活性化方策を探ることが重要な課題であることを明らかにした。
\end{abstract}

はじめに

環境問題が地球的課題となっている中で，市街化が激しく進め られている韓国の大都市地域では，地価の高騰とともに都市内の 自然の緑が急速に消失しつつあり, 都市環境やアメニティにとっ て多くの問題点が表出しつつある。このような背景の中で, 韓国 の大都市における都市緑地，特に都市環境に影響の大きい都市内 大規模緑地に対しては, レクリエーション需要への対応とともに 良好な都市環境の形成に寄与する保全の必要性が高まりつつある。

都市緑地に対する研究としては, 従来より, 居住環境として求 められる緑量の測定方法, 市街地内の斜面緑地の保全 ${ }^{1)}$, 緑地環 境の都市比較 ${ }^{2)}$, 都市らしさと緑地景観に関する研究 ${ }^{3)}$ など多様 な研究がなされている。筆者らも, 人間の意識評価を通じて緑地 が保有する各種の効果を明らかにする評価手法の開発とともに計 画技法へのアプローチが重要な意味を持つとの観点から, 保存緑 地に対する居住者の意識評価への影響要因を保存緑地の持つ物的 諸特性之の関わりあいから探る研究価交進めてきている。

本研究では, 韓国の大邱市に存在する 7 力所の大規模な都市緑 地を対象とし，都市緑地が保有する物的ポテンシャルをメッシュ アナリシスを用いて保全と活用の視点から評価するとともに, 都 市居住者へのアンケート調査を通じて都市緑地の利用状況と各種 効果に対する意識評価を明らかにし, 物的ポテンシャルの評価と 居住者の意識評価との相互関係を捉えることにより，保全と活用 の視点から都市緑地の整備の方向性を探ることを目的とした。

\section{1. 研究の方法}

本研究では, 韓国大邱市において現況林が含まれている $150 \mathrm{ha}$ 以上の 7 力所の大規模な都市緑地を調查対象として設定し, 物的 ポテンシャルを捉えるためのメッシュアナリシスと居住者の都市 緑地に対する意識評価を把握するためのアンケート調查を実施し た。なお，図-1に 7 力所の都市緑地の位置を示している。

(1) 物的ポテンシャル調査

物的ポテンシャルは, 平成 4 年韓国国土地理院発行の $1 / 25,000$ の地形図をべースとした一辺 $250 \mathrm{~m}$ を単位メッシュと するメッシュアナリシスを通じて把握した。

メッシュアナリシスでは，上記の地形図を用いて，地形傾斜は $30^{\circ}$ 以上, $15^{\circ} \sim 30^{\circ}, 15^{\circ}$ 未満に分類し, 眺望度は独立峰, 1 次 及び 2 次尾根から $1 \mathrm{~km}$ 以上の眺望可能な方位を, 全 8 方位の内,
7 方位以上, $4 \sim 6$ 万位, 3 方位以下に分類し，交通施設は道路 を道路幅員 $1.5 \mathrm{~m}$ 末満を山道, $1.5 \sim 5.5 \mathrm{~m}$ を歩車共用道, $5.5 \mathrm{~m}$ 以上を自動車道に分類した。植生レベルは $1 / 25,000$ (韓国山林 宁発行, 1986 年)の相観植生図を用いて, 自然植生, 代償植生を ランク 1 , 植林地, 草原をランク 2 , 農耕地, 造成地, 市街地を ランク 3 に分類した。次いで，大邱市自然環境資料集 ${ }^{\text {? }}$ を用い て, 自然景観資源としては河川, 池, 滝, 山頂, 峰, 人文景観資 源としては史跡，社寺，城跡，レクリエーション資源としては休 養・休息施設, 運動施設, 教化施設, 宿泊施設を読み取った。

なお，地形傾斜，植生レベルは単位メッシュにおいて最大面積 を占める分類項目をその単位メッシュの内容として代表させ，そ の他の項目に関しては, 分類項目の存在の有無をそのメッシュの 内容とした。

\section{(2) アンケート調査}

アンケート調查は，大邱市内の 7 つ海に無作為に 300 名の 被験者を抽出し, 平成 7 年 8 月末にアンケート調查票を配布し, 9 月中旬に郵送回収する留置方式で実施した。配布数は 2,100 票, 有効回収数は 484 票で有効回収率は $23.0 \%$ であった。設問は, 1 . 利用経験のある緑地と最むよく利用する緑地の抽出，2.最もよく 利用する緑地の利用目的と利用頻度，3.最もよく利用する緑地に

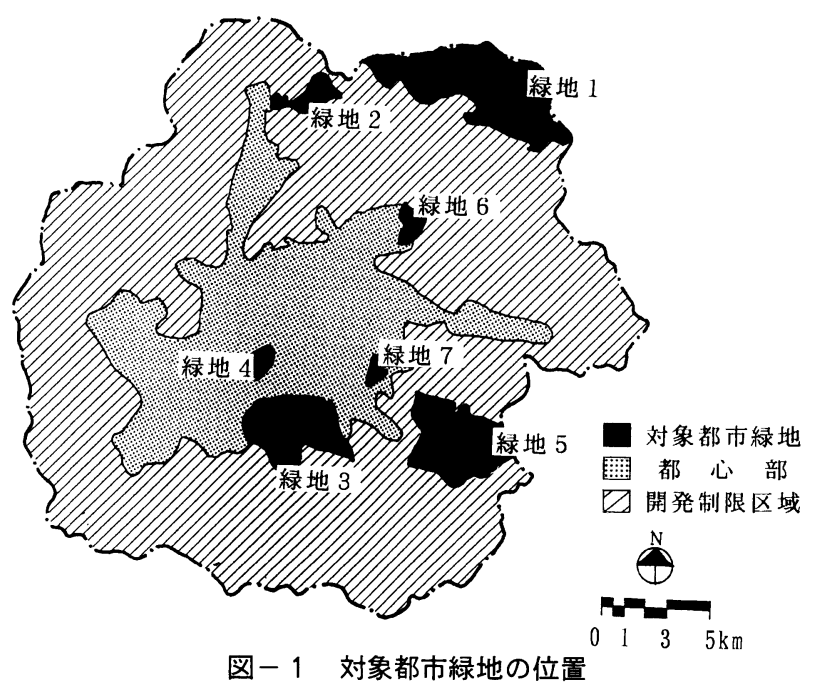

*大阪府立大学農学部 
対する現況評価とその緑地がもたらす各種効果の評価, 被験者属 性に関する設問で構成した。

なお, 本研究の解析対象とした設問は, 1 .の最もよく利用する 緑地の抽出数, 2.の利用目的と 3. の現況評価之効果の評価である。

利用目的は図-3に示す 8 項目で複数回答を求め, 現況評価は 表一 2 に示す 10 項目に対して「非常に満足〜非常に不満」の 5 段階尺度を用い，効果の評価は表一 3 に示す 12 項目に対して 「非常に感じる〜感じない」の 4 段階尺度を用いて評価を求めた。

\section{（3）解析方法}

物的ポテンシャルは，計測によって得たメッシュデータを表一 1 に示すように全メッシュ数に対する割合（\%) と各緑地の都市 の土地利用現況図上の位置図から把握した。

アンケートの解析では, 最むよく利用する緑地の抽出数と利用 目的は単純集計，現況評価については 10 の評価項目に対する 5 段階尺度にそれぞれ非常に不満を 1 点から非常に満足を 5 点の評 価点を与え, 各緑地毎に各々の被験者の評価点を基礎データとし て因子分析(バリマックス法)を行い，その因子負荷量を用いて各 緑地別の意識評価の構造を把握した。次いで, 各緑地毎の項目別 平均評価点を算出し，その評価点を用いて考察を進めた。緑地が あたらす効果に対する評価特性については，12 の評価項目に対 する 4 段階尺度にそれぞれ感じないを 1 点から非常に感じるを 4 点の評価点を与え, 各緑地毎に各々の被験者の評価点を基礎デー 夕として因子分析(バリマックス法)を行い，その因子負荷量を用 いて各緑地別意識評価の構造を把握した。

\section{2. 解析結果及び考察}

\section{(1) 物的ポテンシャルの解析結果}

表一 1 は,メッシュアナリシスから得た物的諸特性を示してい る。図一 1 および表一 1 から各緑地の物的ポテンシャルを捉える と, 緑地 1 は市街地と開発制限区域を隔てた郊外部に位置する大 邱市を代表する緑地であり, 歴史的に由緒ある古い寺が 2 力所存 在し，歴史的に市民から親しまれてきた緑地である。主に $15^{\circ}$ 以 上の急傾斜地で構成されており, 自然植生あるいは代償植生によっ て90\%のエリアが覆われている。また，自然景観資源は，河川 を中心にやや多く主に自然性が非常に高い緑地である。さらに, 緑地内の山道の整備状況は良い。緑地 2 は, 緑地 1 に隣接する郊 外部に位置し，松林の有名な所として昔ながら地名は知られてい る。山麓部を多く含んでいることから緩斜面も多く占めており, 植生は自然植生あるいは代償植生が 80\%程度占めている。また, レクリエーション資源はなく, 緑地内外ともアクセス性が低い状 況にある。緑地 3 は, 市街地の外延部に位置しているあのの市街 地と接する部分に道路と中高層の住宅団地が遮っており一般市街 地からのアクセス性が低い状況にある。また，山麓部の入口には 施設ゾーンが整備されているほか, 昔からの名所となっておりケー
ブルカーが敷設されている。1 $15^{\circ}$ 以上の急傾斜面が大部分を占め ており，自然植生あるいは代償植生によって $90 \%$ のエリアが覆 われ，自然景観資源は河川を中心にやや多く主に自然性が非常に 高い緑地である。緑地内の山道の整備は非常に高い水準にある。 緑地 4 は, 市街地の中心部の独立した丘陵であり, 大部分の市街 地から眺望できる緑地である。ほとんどが緩傾斜地で構成されて おり, 造成地を多く含んでいる。緑地内では, 山道や歩車共有道 が多く整備されているほか, レクリエーション資源も多く存在し 特に利用性が高い緑地である。緑地 5 は, 緑地 1,2 と同様に郊 外部に位置しており, 道路整備が遅れていることからアクセス性 は低い状況にある。ほとんどが急傾斜地で構成され，自然植生あ るいは代償植生によって 80\%強のエリアが覆われている。レクリ エーション資源は殆ど含まない自然性だけが非常に高い緑地であ る。緑地 6 は, 市街地の外延部に位置しており, 近年, 古墳公園 として整備されつつある。ほとんどが緩傾斜地で構成され，多く の草原を含んでいる。緑地内では山道の整備水準が高くレクリエー ション資源むやや含まれている。緑地 7 は, 市街地の外延付近に 位置し, 緩傾斜地で構成され, 草原を多く含む緑地であり, レク リエーション資源はやや存在するすのの山道の整備率は低い状況 にある。

\section{（2）意識評価の解析結果}

(i ）最むよく利用される緑地とその利用目的

図一 2 は, 最むよく利用する緑地として指摘された回答数を示 し, 図一 3 は, その利用目的の構成比を示している。

最むよく利用する緑地として指摘された緑地を見ると, 緑地 1 は, 全回答数の $40 \%$ 以上 (210 人) を占め, 大邱市で圧倒的によ く利用される緑地であることが読み取れる。次いで, 緑地 3 と 4 はそれぞれ 104 人, 89 人と $20 \%$ 程度占めており, かなり利用さ れている。一方, 緑地 5 と 7 はそれぞれ 11 人と 14 人と非常に少 なく, 緑地 2 と 6 万 30 人と 26 人と少ない状況にある。

上位 3 緑地の利用目的を見ると, 緑地 1 では, 散歩, 自然鑑賞 などの休養の場，人との付き合いの場がそれぞれ $42.3 \%, 38.5 \%$, $33.3 \%$ 静的利用が中心となっており, 運動・スポーツは $20.9 \%$ である。緑地 3 では, 散歩, 自然鑑賞などの休養の場といった静 的利用がそれぞれ $50.9 \%, 40.3 \%$ と高いものの運動・スポーツ む $36.5 \%$ と高くなっている。緑地 4 は, 散歩が $47.1 \%$ とや飛 び抜けて高く, 次いで, 人との付き合いの場, 運動・スポーツ, 自然鑑賞などの休養の場がそれぞれ $37.0 \% ， 34.8 \% ， 33.7 \%$ と続 いている。

以上の解析結果と各緑地が保有する物的ポテンシャルとの相互 関係を捉えると, 緑地 1 は市街地と一般の利用が制限されている 開発制限区域（都市のスプロール防止や周辺自然環境及び国家保 安上開発が制限区域）を挟んで隔てているものの利用が最も活性 化している理由は, 歴史的に由緒のある寺院を 2 力所含んでおり,

\begin{tabular}{|c|c|c|c|c|c|c|c|c|c|c|c|c|c|c|c|c|}
\hline & \multirow[b]{2}{*}{$\begin{array}{l}x \text { メシュ数 } \\
\text { (面樍) }\end{array}$} & \multicolumn{3}{|c|}{ 地形傾斜 } & \multicolumn{3}{|c|}{ 植生レベル } & \multicolumn{3}{|c|}{ 眺望度 } & \multicolumn{3}{|c|}{ 交通施設 } & \multirow[b]{2}{*}{ 自然買源 } & \multirow[b]{2}{*}{ 人䝺纇 } & \multirow[b]{2}{*}{ 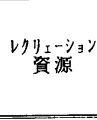 } \\
\hline & & $\begin{array}{l}30^{\circ} \\
\text { 资 }\end{array}$ & $\begin{array}{l}15^{\circ} \\
30^{\circ}\end{array}$ & $\begin{array}{l}15^{\circ} \\
\text { 粫 }\end{array}$ & $\begin{array}{l}5 \\
3 \\
y \\
1\end{array}$ & \begin{tabular}{l}
\multirow{3}{*}{} \\
3 \\
2 \\
\end{tabular} & $\begin{array}{l}5 \\
⿱ 亠 䒑 \\
3 \\
3 \\
\end{array}$ & $\begin{array}{c}7 \\
\text { 方位 } \\
\text { 上 }\end{array}$ & $\begin{array}{l}4 \sim 7 \\
\text { 方位 }\end{array}$ & \begin{tabular}{c|}
3 \\
方位
\end{tabular} & $\begin{array}{l}1.5 \mathrm{~m} \\
\text { 奖 }\end{array}$ & $\begin{array}{l}1.5 \mathrm{~m} \\
5.5 \mathrm{~m}\end{array}$ & $\begin{array}{c}5.5 \mathrm{~m} \\
\text { 尘 }\end{array}$ & & & \\
\hline 緑地 I & $\begin{array}{c}514 \\
3200 \text { ha } \\
\end{array}$ & \begin{tabular}{l|}
60 \\
$13 \%$ \\
\end{tabular} & $\begin{array}{c}344 \\
67 x \\
\end{array}$ & $\begin{array}{c}110 \\
218 \\
\end{array}$ & \begin{tabular}{|c|}
461 \\
$90 \%$ \\
\end{tabular} & \begin{tabular}{l|}
2 \\
18 \\
\end{tabular} & \begin{tabular}{l|}
51 \\
$10 \%$ \\
\end{tabular} & $\begin{array}{c}13 \\
3 x \\
\end{array}$ & $\begin{array}{l}63 \\
128 \\
\end{array}$ & $\begin{array}{c}32 \\
6 x \\
\end{array}$ & $\begin{array}{c}147 \\
29 \% \\
\end{array}$ & $\begin{array}{c}42 \\
8 \% \\
\end{array}$ & \begin{tabular}{c|}
25 \\
$5 \%$ \\
\end{tabular} & $\begin{array}{c}130 \\
25 \%\end{array}$ & $\begin{array}{c}13 \\
38 \\
\end{array}$ & $\begin{array}{c}14 \\
3 x \\
\end{array}$ \\
\hline 緑地 2 & \begin{tabular}{c|}
68 \\
430 ha \\
\end{tabular} & \begin{tabular}{l|}
11 \\
$16 \%$ \\
\end{tabular} & \begin{tabular}{|l|}
31 \\
$46 \%$ \\
\end{tabular} & \begin{tabular}{l|}
26 \\
$38 x$ \\
\end{tabular} & \begin{tabular}{l|}
56 \\
828 \\
\end{tabular} & \begin{tabular}{l|}
6 \\
$9 x$ \\
\end{tabular} & \begin{tabular}{l|}
6 \\
98 \\
\end{tabular} & \begin{tabular}{l|}
2 \\
38 \\
\end{tabular} & \begin{tabular}{|l|}
3 \\
$4 \%$ \\
\end{tabular} & \begin{tabular}{|l|}
2 \\
$3 x$ \\
\end{tabular} & $\begin{array}{l}12 \\
18 \% \\
\end{array}$ & \begin{tabular}{l|}
4 \\
$6 x$ \\
\end{tabular} & \begin{tabular}{|l|}
11 \\
$16 \%$ \\
\end{tabular} & $\begin{array}{l}27 \\
40 \% \\
\end{array}$ & $\begin{array}{l}2 \\
3 x \\
\end{array}$ & $\begin{array}{l}0 \\
0 \% \\
\end{array}$ \\
\hline 緑地 3 & $\begin{array}{c}265 \\
1600 \mathrm{ha}\end{array}$ & \begin{tabular}{|l|}
44 \\
178 \\
\end{tabular} & \begin{tabular}{|c|}
183 \\
698 \\
\end{tabular} & \begin{tabular}{|l|}
37 \\
148 \\
\end{tabular} & \begin{tabular}{|c|}
239 \\
$90 \%$ \\
\end{tabular} & \begin{tabular}{c|}
12 \\
$5 x$ \\
\end{tabular} & \begin{tabular}{c|}
13 \\
$5 *$ \\
\end{tabular} & \begin{tabular}{l|}
5 \\
28 \\
\end{tabular} & $\begin{array}{l}27 \\
10 \% \\
\end{array}$ & \begin{tabular}{|l|}
8 \\
$3 x$ \\
\end{tabular} & \begin{tabular}{|l|}
83 \\
$31 \%$ \\
\end{tabular} & $\begin{array}{c}25 \\
98 \\
\end{array}$ & \begin{tabular}{c|}
18 \\
$7 \times$ \\
\end{tabular} & $\begin{array}{l}63 \\
24 \% \\
\end{array}$ & $\begin{array}{c}11 \\
4 x \\
\end{array}$ & $\begin{array}{l}6 \\
2 x \\
\end{array}$ \\
\hline 緑地 4 & $\begin{array}{c}29 \\
180 \mathrm{ha} \\
\end{array}$ & $\begin{array}{l}0 \\
0 \% \\
\end{array}$ & $\begin{array}{c}3 \\
10 \% \\
\end{array}$ & \begin{tabular}{l|}
26 \\
$90 \%$ \\
\end{tabular} & \begin{tabular}{l|}
11 \\
$38 \%$ \\
\end{tabular} & \begin{tabular}{c|}
7 \\
248 \\
\end{tabular} & \begin{tabular}{l|}
11 \\
$38 x$ \\
\end{tabular} & \begin{tabular}{l|}
2 \\
$7 x$ \\
\end{tabular} & $\begin{array}{c}4 \\
14 \% \\
\end{array}$ & $\begin{array}{l}1 \\
3 x \\
\end{array}$ & $\begin{array}{l}0 \\
0 \% \\
\end{array}$ & \begin{tabular}{l|}
15 \\
$52 \%$ \\
\end{tabular} & \begin{tabular}{|l|l|}
12 \\
$41 \%$ \\
\end{tabular} & $\begin{array}{c}5 \\
17 \% \\
\end{array}$ & $\begin{array}{l}1 \\
3 x \\
\end{array}$ & $\begin{array}{r}9 \\
31 x \\
\end{array}$ \\
\hline 緑地 5 & $\begin{array}{c}313 \\
2000 \text { ha } \\
\end{array}$ & $\begin{array}{l}42 \\
14 \% \\
\end{array}$ & $\begin{array}{c}201 \\
64 \% \\
\end{array}$ & \begin{tabular}{l|}
70 \\
$22 \%$ \\
\end{tabular} & \begin{tabular}{|c|}
263 \\
$84 \%$ \\
\end{tabular} & $\begin{array}{c}27 \\
9 \% \\
\end{array}$ & \begin{tabular}{c|}
23 \\
$7 \%$ \\
\end{tabular} & $\begin{array}{c}13 \\
4 x \\
\end{array}$ & \begin{tabular}{|l|}
34 \\
$11 \%$ \\
\end{tabular} & $\begin{array}{l}7 \\
2 x \\
\end{array}$ & $\begin{array}{l}75 \\
24 \% \\
\end{array}$ & $\begin{array}{l}33 \\
11 \% \\
\end{array}$ & \begin{tabular}{l|}
0 \\
$0 \%$ \\
\end{tabular} & $\begin{array}{l}67 \\
21 \% \\
\end{array}$ & $\begin{array}{l}2 \\
1 \% \\
\end{array}$ & $\begin{array}{l}0 \\
0 \%\end{array}$ \\
\hline 緑地 6 & \begin{tabular}{c||}
42 \\
275 ha \\
\end{tabular} & $\begin{array}{l}0 \\
0 x \\
\end{array}$ & $\begin{array}{c}9 \\
21 \% \\
\end{array}$ & \begin{tabular}{l|}
33 \\
$79 \%$ \\
\end{tabular} & \begin{tabular}{l|}
23 \\
$55 \%$ \\
\end{tabular} & \begin{tabular}{|l|}
14 \\
$33 \%$ \\
\end{tabular} & \begin{tabular}{c|}
5 \\
$12 \%$ \\
\end{tabular} & \begin{tabular}{l|}
1 \\
$2 x$ \\
\end{tabular} & $\begin{array}{c}4 \\
10 \% \\
\end{array}$ & $\begin{array}{l}3 \\
7 \% \\
\end{array}$ & \begin{tabular}{|l|}
12 \\
$29 \%$ \\
\end{tabular} & \begin{tabular}{|c|}
4 \\
$10 \%$ \\
\end{tabular} & \begin{tabular}{c|}
6 \\
148 \\
\end{tabular} & $\begin{array}{l}15 \\
36 \% \\
\end{array}$ & $\begin{array}{c}7 \\
17 \% \\
\end{array}$ & $\begin{array}{c}5 \\
128 \\
\end{array}$ \\
\hline 緑地 7 & $\begin{array}{c}22 \\
150 \mathrm{ha} \\
\end{array}$ & $\begin{array}{l}0 \\
0 \%\end{array}$ & $\begin{array}{l}0 \\
0 \%\end{array}$ & $\begin{array}{c}22 \\
100 \% \\
\end{array}$ & \begin{tabular}{|l|}
12 \\
548 \\
\end{tabular} & \begin{tabular}{c|}
7 \\
$32 \%$ \\
\end{tabular} & \begin{tabular}{|c|}
3 \\
$14 \%$ \\
\end{tabular} & $\begin{array}{l}2 \\
98 \\
\end{array}$ & $\begin{array}{c}4 \\
18 \% \\
\end{array}$ & $\begin{array}{l}1 \\
5 x\end{array}$ & $\begin{array}{c}3 \\
14 \% \\
\end{array}$ & $\begin{array}{c}7 \\
32 x \\
\end{array}$ & \begin{tabular}{|c|}
3 \\
$14 x$ \\
\end{tabular} & $\begin{array}{l}2 \\
9 \% \\
\end{array}$ & $\begin{array}{l}1 \\
5 \%\end{array}$ & $\begin{array}{c}4 \\
18 \% \\
\end{array}$ \\
\hline
\end{tabular}




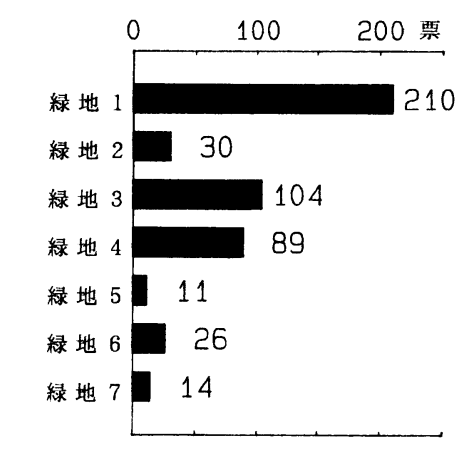

図ー2 最もよく利用する緑地の回答数

住民との歷史的つながりが最も深いことが大きな要因と考えられ る。そのような中で，豊かな自然と歴史的な人文資源を背景とし て, コミュニティの場や静的な利用の場として利用されているも のと考えられる。次いで, 利用の活性化している緑地 3 は, ケ一 ブルカーが整備されているように古くからの大邱市の名所である とともに市街地の外延に接していることや山麓部にスポーツ施設 が整備されていることによって利用の活性化が図られていると考 えられ, 利用目的にもその傾向が現れている。緑地 4 は, 市街地 の中心部に存在する独立した丘陵であり日常的に行動的にも視覚 的にも住民と接触が最も高い緑地であることから利用の活性化が 図られているものと考えられ，第 1 位の利用目的である散歩にも その傾向が現れている。一方, 利用が最も不活性な緑地 5 と 7 は, 開発制限区域を隔てた位置と市街地の外延部付近に位置しており, 住民と日常的に視覚的な接触が少ない上に特筆すべき資源や歴史 的な背景もなく，一見すると通常の山と何等変わらないことから 利用の不活性が起こっているあのと考えられる。また, 緑地 2 と 6 は, 若干利用されているが, これは, 緑地 2 が松林として歴史 的に有名であったといった歷史的背景が存在することと緑地 6 は 近年古墳公園として整備が進捗しつつあることによるものと考え られる。

なお, 以下の解析は, サンプル数む多く大邱市での重要な緑地 として位置づけられる上位 3 緑地に対して進めるものとした。

(ii) 現況評価に対する意識構造と評価結果

表一 2 は，各緑地ごとに現況に対する評価結果の個人デー夕を 用いた因子分析結果の因子負荷量を示しており，図一 4 は，3 緑 地の平均評価点のプロフィールを示している。

表一 2 から, 各緑地の現況評価に対する意識構造をみると，緑 地 1 では, 評価の主軸となる第 1 因子はトレッキングなどの運動 のしやすさ, 自然観賞など休息のしやすさ, 散歩道の歩きやすさ が 0.5 以上の高い值を示し, 第 2 因子は草花の豊かさ, 第 3 因子 は景色展望の良さが 0.5 以上の高い值を示す。緑地 3 では, 第 1

表 -2 現況評価の意識構造

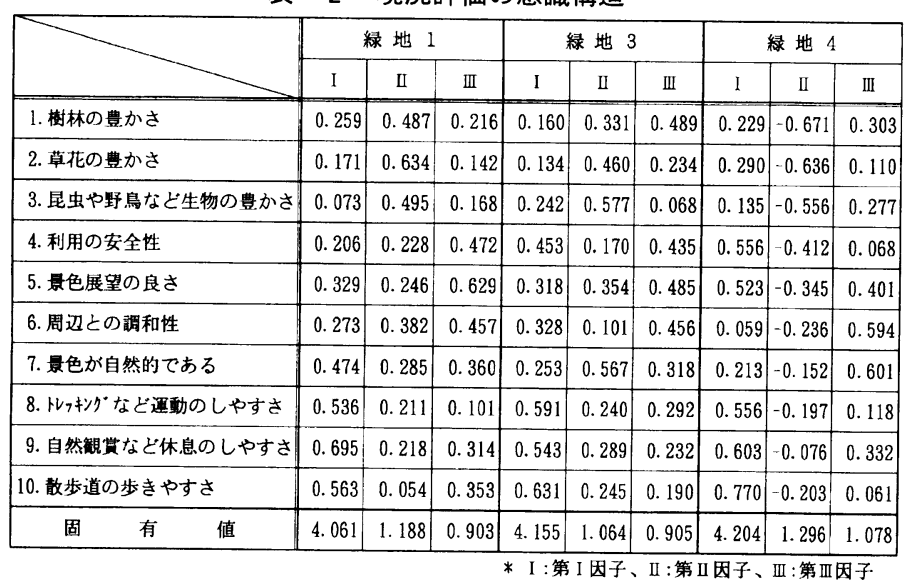

因緑地 1 と同様の 3 項目が 0.5 以上の高い值を示し，第 2 区 子は昆虫や野鳥などの生物の豊かさと景色が自然的であるが 0.5 以上の高い值を示すが，第 3 因子では 0.5 以上の高い值を示す項 目はない。緑地 4 では, 第 1 因子は緑地 1 と同様の 3 項目に加え 利用の安全性, 景色展望の良さが 0.5 以上の高い值を示し, 第 2 因子は, 項目 1 の樹林の豊かさから項目 3 の生物の豊かさがマイ ナス 0.5 以上の高い值を示し, 第 3 因子は周辺との調和性, 景色 が自然的であるが 0.5 以上の高い值を示す。

次に図 -4 から， 3 緑地の現況評価結果を見ると, 評価の傾向 は全体的に似ており, 草花の豊かさと生物の豊かさの 2 項目だけ がプラス側の評価になっており, 他の評価項目はほぼどちらでも ないといった中間値付近の值を示している。3 緑地で評価が若干 異なる点は, 緑地 1 では, 項目 1 の樹林の豊かさから項目 3 の生 物の豊かさと項目 7 の景色が自然的であるといった自然供給に関 する項目が他の 2 緑地に比較して高い点である。一方, 緑地 4 で は, 利用の安全性と散歩道の歩きやすさといった利用面に関する 項目が若干高くなっており, 緑地 3 は, 緑地 1 と緑地 4 の中庸な 評価を示している。

以上の解析結果と各緑地が保有する物的ポテンシャルとの相互 関係を捉えると, 緑地 1 は市街地と開発制限区域を挟んだ郊外部 に位置し豊かな自然環境を保有していることから, 自然地域内で の活動に対する点が強く意識され, 次いで, 自然環境面, 最後に 利用面や景観面が意識されたものと考えられ，この意識構造は自 然供給面での評価が高いといった結果にも反映されている。一方 緑地 4 は, 市街地の中心部に存在し草地や造成地なども多く含ん でいることから, 自然地域内での活動とともに利用面や景観面も 強く意識されるが自然環境面の意識が弱くなったものと考えられ, この意識構造は現況評価の結果にも反映されている。また, 緑地 3 は市街地の外延部に位置し緑地 1 と同様に豊かな自然環境を保 有していることから, 緑地 1 と緑地 4 の両面が意識されたものと 考えられる。 
表 -3 各種効果の評価構造

\begin{tabular}{|c|c|c|c|c|c|c|c|c|c|c|}
\hline & \multicolumn{3}{|c|}{ 線地 1} & \multicolumn{3}{|c|}{ 緑地 3} & \multicolumn{3}{|c|}{ 緑地 4} \\
\hline & & I & II & III & I & II & III & I & II & III \\
\hline 景観 & 1. 都市の美しさ & 0.253 & -0.767 & 0.243 & 0.138 & -0.802 & 0.229 & 0.807 & 0.244 & 0.181 \\
\hline 殁成 & 2. 都市の速力 & 0.176 & -0.750 & 0.247 & 0.182 & -0.821 & 0.172 & 0.755 & 0.209 & 0.314 \\
\hline \multirow[t]{2}{*}{ 効果 } & 3. 景色の請和 & 0.272 & 0.601 & 0.268 & 0.333 & -0.627 & 0.277 & 0.639 & 0.111 & 0.535 \\
\hline & 4. 緑の豊かさ & 0.313 & -0.451 & 0.447 & 0.583 & -0.439 & 0.395 & 0.685 & 0.284 & 0.376 \\
\hline 利用 & 5. 緑地空間利用の㭗しさ & 0.325 & -0.288 & 0.537 & 0.661 & -0.249 & 0.214 & 0.546 & 0.503 & 0.257 \\
\hline \multirow[t]{4}{*}{ 効果 } & 6. 人々との付き合い安さ & 0.115 & -0.105 & 0.509 & 0.475 & -0.029 & 0.076 & 0.303 & 0.496 & 0.404 \\
\hline & 7. 生活の罣い & 0.195 & -0.272 & 0.544 & 0.534 & -0.249 & 0.293 & 0.249 & 0.213 & 0.598 \\
\hline & 8. 自然に対する親しみ & 0.398 & -0.317 & 0.597 & 0.537 & -0.193 & 0.468 & 0.517 & 0.267 & 0.490 \\
\hline & 9. 災害からの安心忽 & 0.210 & -0.165 & 0.328 & 0.467 & -0.239 & 0.333 & 0.191 & 0.202 & 0.615 \\
\hline 微 & 10. 空気のさわやかさ & 0.705 & -0.236 & 0.309 & 0.358 & -0.280 & 0.608 & 0.468 & 0.543 & 0.234 \\
\hline 気象 & 11. 四季の麥化（季節感） & 0.586 & -0.156 & 0.222 & 0.173 & -0.163 & 0.663 & 0.075 & 0.626 & 0.133 \\
\hline \multirow[t]{2}{*}{ 効果 } & 12. 夏の涼しさ & 0.695 & -0.292 & 0.225 & 0.225 & -0.217 & 0.674 & 0.502 & 0.537 & 0.271 \\
\hline & 固 & 5.443 & 1.116 & 1.032 & 5.570 & 1.287 & 1.044 & 6.425 & 1.095 & 0.964 \\
\hline
\end{tabular}

\section{（3）各種効果に対する評価構造}

表一 3 は, 各緑地ごとに各種効果に対する評価結果の個人デー 夕を用いた因子分析結果の因子負荷量を示している。

緑地 1 を見ると, 評価の主軸となる第 1 因子では空気のさわや かさ, 四季の変化, 夏の涼しさが 0.5 以上の高い值を示し, 第 2 因子では都市の美しさ, 都市の魅力, 景色の調和がマイナスの 0.5 以上の高い值を示し, 第 3 因子では緑地空間の利用の楽しさ, 人々との付き合い安さ，生活の潤い，自然に対する親しみが 0.5 以上の高い值を示している。緑地 3 を見ると, 第 1 因子では項目 6 の人々との付き合い安さを除く項目 4 の緑の豊かさから項目 8 の自然に対する親しみが 0.5 以上の高い值を示し, 第 2 因子では 項目 1 の都市の美しさから項目 3 の景色の調和がマイナスの 0.5 以上の高い值を示し, 第 3 因子では, 項目 10 の空気のさわやか さから項目 12 の夏の涼しさが 0.5 以上の高い值を示している。 緑地 4 を見ると，第 1 因子では項目 1 の都市の美しさから項目 5 の緑地空間利用の楽しさが 0.5 以上の高い值を示し, 第 2 因子で は都市の美しさ, 自然に対する親しみ, 災害からの安心感が 0.5 以上の高い值を示し, 第 3 因子では項目 10 の空気のさわやかさ から項目 12 の夏の涼しさが 0.5 以上の高い值を示している。

以上の解析結果と各緑地が保有する物的ポテンシャルとの相互 関係を捉えると, 緑地 1 は, 市街地と開発制限区域を挟んで隔たっ た位置にあり, 3200ha といった広大な規模でしかもその面積の 90\%が自然植生あるいは代償植生に覆われていることから, 第 2 因子によって表される都市環境にとっての景観形成効果は意識さ れないものの, 第 1 因子によって表される植生が生み出す微気象 調節効果が強く意識されたものと考えられる。さらに歴史的な背
景を保有した緑地であることから，第 3 因子によって表される緑 地の利用効果も若干意識されている。一方, 市街地の中心部に独 立した丘陵として存在する緑地 4 は, 市街地の大部分から眺望す ることができることから，第 1 因子に景観形成効果が第 1 義的に 意識され, 次いで, 第 2 因子に防災面と利用効果が意識されたも のと考えられる。一方，市街地の中心部にあって面的にまとまっ た樹林を保有していることから，第 3 因子によって表される植生 が生み出す微気象調節効果も若干意識されたものと考えられる。 緑地 3 は, 市街地の外延部に存在するものの一般市街地とは中高 層の住宅団地によって分断された位置にあり，1600ha といった 広大な規模でしかもその面積の $90 \%$ が自然植生あるいは代償植 生に覆われていることから, 第 2 因子によって表される都市環境 にとっての景観形成効果は意識されないものの, 第 1 因子で植生 が生み出す自然性の供給効果と利用が強く意識されたものと考え られる。さらに，第 3 因子によって表される植生が生み出す微気 象調節効果も若干意識されている。

\section{4.まとめ}

以上の解析および考察結果から, 都市緑地の利用および緑地が 保有する各種効果の評価は, 緑地と居住者との視覚的接触ととも に行動的接触の度合いを左右する緑地の立地位置とアクセス性, さらに，心理的接触の度合いを左右する歴史的文化的背景ととも に緑地の内部条件に大きく依存していることが明らかとなった。 すなわち, 市街地と何等かの条件で視覚的接触の分断された緑地 では, 景観形成効果は期待されないこと, 一方, 市街地からの眺 望性か確保された緑地では景観形成効果への期待が高まることが 明らかとなった。また，利用行動の活性化には，緑地が保有する 歴史的背景が大きく寄与しており, 心理的接触が重要な要素であ ることが明らかとなった。特に, 大邱市での都市緑地の利用は, 日本でいう物見遊山的利用が中心となっており，この歷史的文化 的背景は今後の緑地整備において充分配慮すべき事項であると考 えられる。さらに, 利用行動を高めるためには, 緑地へのアクセ ス性を高めるとともに, 緑地内部の動線空間の整備が重要な視点 であるといえるが，何れの緑地に対しても，豊かな植生や市街地 内部でのまとまった樹林地が与える微気像調節効果や自然性の供 給効果が期待されている点や, 自然環境を背景として緑地の利用 や存在効果が顕在化していることから，自然環境の保全を基調と した活性化方策を探ることも重要な点である。

なお，本論文における，大阪府立大学緑地環境計画工学研究室 の先生方の, 懇切丁寧な指導に対し感謝申し上げる。

\section{参考文献}

1）金子忠一 (1989): 市街地内斜面緑地 の保全に関する研究：造園雑誌 52(5), 294-299

2 ）浅川昭一郎他 (1983)：緑地環境の都 市比較に関する研究：造園雑誌 46(5), 235-240

3 ) 久保 貞他 (1984）: 都市らしさと緑
地景観に関する研究：造園雑誌 47(5), 177-182

4) 鈴木智子他 (1990)：ニュータウン内 の保存緑地評価に関する研究: 造園雑 誌 53(5), 365-370

5 ）權 奇燦他 (1991)：二ュータウン内 の保存緑地活用計画に関する研究 : 造 園雑誌 54(5)，257-262
6 ）權 奇燦他（1994）: 住民意識調査を 通じたニュータウン内の保存緑地が保 育する各種の効果に関する研究 : 造園 雑誌 57(5)，187-192

7 ）大邱直轄市（1982）: 大邱の香り：三 一社

8 ）大邱直轄市 (1986)：八公山：三一社

Summary: The purpose of the paper is to point out the direction of maintenance of urban forests from the viewpoint of conservation and practical use of the 7 large scale urban forests existed in Teagu, Korea by catching the relationship of consciousness evaluation from the residents and evaluation results of the physical potential of the urban forests. It is shown that the forests are used as a jaunt place same as that in Japan in Edo era. Such kind of historical and cultural background should be considered sufficiently for the maintenance of the forests in the future. Natural environment which has the function of providing urban forests as the background, it is a very important issue to find out the revitalization policy for urban forests based on the conservation of natural environment, because the revitalization of using urban forests,its micro-whether controlling effect and its naturalness supplying effect etc. are becoming actual. 